African J. Biol. Sci., 17 (1): 297-319 (2021)

ISSN 1687-4870

e- ISSN 2314-5501 (online)

www.ajbs.journals.ekb.eg

E.mail: aasdjournal@yahoo.com

\title{
Microplastics contamination of fish from the Creeks along the Kenya coast, western Indian Ocean (WIO)
}

\author{
Kerubo J.O. ${ }^{1 *}$, Muthumbi A.W.N. ${ }^{1}$, Deborah Robertson- Andersson ${ }^{2,3}$, Onyari J.M. ${ }^{4}$ and \\ Kimani E.N. ${ }^{5}$ \\ 1Faculty of Science and Technology, Univ. of Nairobi, P O. Box 30197-00100, Nairobi, Kenya. \\ 2 School of Life Sciences, Univ. of KwaZulu-Natal, P.O. Private Bag X54001, Durban, South Africa. \\ 3-Chrysalis Nature Training, Kei mouth. \\ 4-Faculty of Science and Technology, Univ. of Nairobi, P.O. Box 30197-00100, Nairobi, Kenya \\ 5-Kenya Marine and Fisheries Research Institute (KMFRI), P.O. Box 81651-80100, Mombasa, Kenya. \\ *Corresponding author: Kerubo JO. e-mail: joycekerubo510@yahoo.com Permanent Postal \\ address: P.O. Box 67838-00200, Nairobi, Kenya.
}

Received: November 3, 2021; Accepted: December 20, 2021; Available online: December 27, 2021

\section{ABSTRACT}

Microplastics (MPs) are a global threat to marine life, but information available on the extent of pollution along the Kenya Indian ocean coast is absent. Ingestion of MPs by five common pelagic fish from the region was investigated in this study. Fish tissues were digested in $10 \%$ potassium Hydroxide $(\mathrm{KOH})$ at $60{ }^{\circ} \mathrm{C}$ for 14 hours and the MPs were separated by floatation method using supersaturated Sodium Chloride $(\mathrm{NaCl})$ solution. The benthic fish studied (Acanthopagrus berda had a mean of $0.48 \pm 0.06$ MPs per gram $\left(\mathrm{g}^{-1}\right)$ tissue, Gerres oyena $0.20 \pm 0.02$, Terapon jarbua $0.20 \pm 0.06$ ) had higher MPs contamination compared to the pelagic (Rastrelligerkanagurta $0.054 \pm 0.011$ ) and reef fish (Leptoscarus vaigiensis $0.038 \pm$ 0.009) reflecting the influence of habits and habitat on MPs contamination in fish. Fish caught in the second sampling had higher MPs contamination compared to the first and fish from Mida Creek had higher MPs contamination compared to those from Tudor and Port-Reitz probably because they were mainly benthic fish. Gut and gills of all species contained significantly higher concentrations of microplastics than the flesh. Thus, we recommend that fish be gutted and thoroughly clean the gills before cooking to reduce MPs contamination. There is need for further research to evaluate the risk posed to humans by the consumption of marine water fish that ingested microplastics

Keywords Microplastic contamination; fish; Creeks; Western Indian Ocean Kenya Coast.

\section{INTRODUCTION}

Pollution of the oceans with microplastics and their potential impact along marine food web through consumption is of increasing concern (Cole et al., 2013; Eerkes- Medrandet al., 2015; Romeo et al., 2015; Beer et al., 2018). Barnes et al. (2009) defined microplastics as synthetic particles measuring $<5 \mathrm{~mm}$ in diameter. They can be primary in nature if they are particles manufactured for product production in which case they are referred to as nurdles or they can be secondary if the particles are degraded from microplastic debris (Lusher et al., 2013; Free et al., 2014). Plastic degradation occurs through physical, microbial and ultra-violet radiation processes (Moore, 2008; Andrady, 2011; Rummel, 2014) although very slowly. Microplastics are further classified as fibers, fragments, films, beads or foams based on shape (Cole et al., 2013; Claessens et al., 


\section{Kerubo J.O. et al.}

2013; Mathalon and Hill, 2014; Hartline et al., 2016). Fibers originate mainly from plastic bags, fishing nets and clothing (Claessens et al., 2013; Hartline et al., 2016), while fragments often originate from plastics that do not unfurl into filamentous threads such as molten plastics or plastic films, filters, and geo textiles (Cole et al., 2011; Claessens et al., 2013).

Due to their large surface area and hydrophobic nature, microplastics absorb a lot of persistent organic particles (POPs) and because of their minute size $(1 \mu \mathrm{m}-5 \mathrm{~mm})$, they can be easily swallowed by a diversity of organisms since they mimic prey particles and sediment grains (Hong et al., 2018). Research has shown that marine invertebrates and vertebrates ingest microplastics (Neves et al., 2015; Van Cauwenberghe et al., 2015; Devriese et al., 2015; Li et al., 2016; Nelms et al., 2018; Awour, 2020) with some such as crabs taking them in through the gills (Wright et al., 2013; Setela et al., 2014; Cole et al., 2015; Weiden and Cowie, 2016; Karlsson et al., 2017). Microplastics transport POPs into marine organisms, as well as plastic additives, such as Bisphenol-A and nonylphenol, which leach out into the organisms (Koelmans et al., 2014). Bioaccumulation and biomagnification of microplastics to higher trophic levels has also been reported (Farrell and Nelson, 2013; Setala et al., 2014).

Microplastics are therefore harmful to organisms along the food webs as well as the environment. For instance, styrene in polystyrene is an endocrine disrupter, while polyester contains hazardous level of monomers associated with respiratory irritation, cell mutation, and is toxic to aquatic environments (Lithner et al, 2011). Polyethylene and polyamides (nylon) although thought to be benign, may absorb POPs from the environment (Rochman et al., 2013) such as pesticides and polychlorinated biphenyls (PCB's), known to disrupt immunity and cell division (Lauby-Secretan et al., 2013; Hable and Nguyen, 2013). Microplastics toxins in low density polyethylene (LDPE) cause liver stress including: single cell glycogen depletion, necrosis, and fatty vacuolation (Rochman et al., 2013). Microplastics have been known to cause inimical physiological effects, leading to a decrease in feeding ability, energy accumulation, and reproduction for small-size organisms at lower Atrophic levels (Cole et al., 2013; Sussarellu et al., 2016). However, information on contamination of fish by microplastics is not well documented (Romeo et al., 2015) creating a knowledge gap, more so, no study has been done on contamination of fish by microplastics along the Kenya Coast.

Owing to the toxic effects of microplastic contamination to organisms along the food webs and the ever-increasing release of plastics into the ocean, it is important to understand the extent of the problem, to effectively mitigate it. Therefore, the main objectives of this study were to; a) assess the presence and abundance of microplastics in the gut, gills and muscles of five of the most common marine fish species from the creeks along the Kenya coast in WIO. b)characterize the microplastics by shape and colour. Considering the importance of the marine trophic web, as prey for big fish and food to humans, this study makes an important contribution to knowledge of microplastics occurrence in fishes in Kenyan inshore waters.

\section{MATERIALS AND METHODS 1. Sampling sites}

The study was carried out in two creeks in Mombasa County (Tudor, PortReitz) and one creek in Kilifi County (Mida) along the Kenya Coast (Fig. 1). The creeks 
Microplastics contamination of fish from the Creeks along the Kenya coast, western Indian Ocean (WIO)

are enclosed and surrounded by informal settlements, highly populated villages, and 2011, 2019; Maritim et al., 2016), hence manufacturing industries (Okuku et al.,

may be prone to plastic pollution.

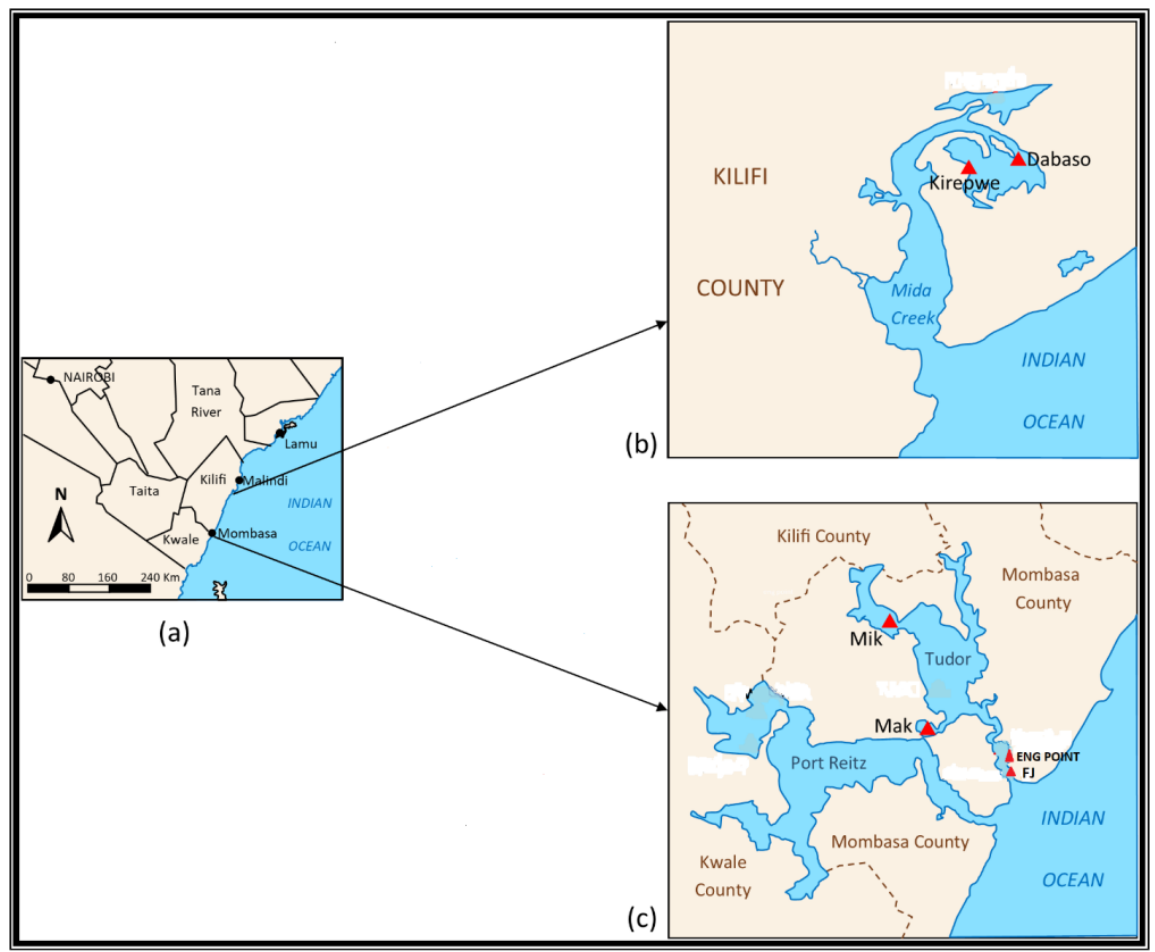

Fig. 1. Map of Kenya showing the study sites a) Kenya Coastal region; b) Mida Creek (Dabaso and Kirepwe); c) Mombasa Island with Tudor (Fort Jesus-FJ, English Point-Eng Point and Mikindani-Mik) and Port-Reitz (Makupa-Mak) Creeks.

The Kenya Coastal region experiences two rainy seasons with two maxima in May and October and an average mean annual rainfall of $1204 \mathrm{~mm}$ (Obiero and Onyando, 2013). The region experiences fairly high average temperatures ranging between 26 and $32^{\circ} \mathrm{C}$, a small diurnal range of between 7 and $9^{\circ} \mathrm{C}$ (Obeiro and Onyando, 2013). Port-Reitz creek receives freshwater from rivers Mwache, Cha Shimba, and Mwambone, while Tudor creek is fed by two main seasonal rivers; Kombeni and Tsalu which arise from around Mariakani town, $32 \mathrm{~km}$ Northwest of Mombasa (Kitheka et al., 1999) (Fig. 1a). Tudor creek passes under Nyali Bridge and is bordered by Makupacauseway which dissects it into Tudor creek to the East and Port-Reitz to the West (Kitheka et al., 1999) (Figure 1c). In port-Reitz Creek, fish samples were analyzed only from Makupa station due to limited availability of fish. Midacreek within Watamu Marine National Park is a semi-pristine environment and was considered as a control (Fig. 1b). In Mida Creek two stations were sampled; that is, Dabaso and Kirepwe. In Tudor fish were sampled from 3 stations; Fort Jesus, English Point and Mikindani while from Port Reitz only Makupa was sampled.

\section{Sampling strategy}

All institutional and national guidelines for the care and use of laboratory 
Kerubo J.O. et al.

animals were followed. Sampling was done in January/February2018 (Jan 2018) during the dry period and in September 2018 (Sept 2018) during the short rainy season to collect fish samples for microplastic extraction and analysis. Fish samples were bought from the local fishers encountered at the sampling stations or the landing sites (Tudor, Port-Reitz and Mida Creeks) and the number and species depended on availability in the catch. At each station, GPS coordinates were recorded (Table 1) using a handheld GPS (version; Mitac mio168).

Table 1.Longitude and latitudes of Sampling stations of the Creeks along the Kenya coast, western Indian Ocean.

\begin{tabular}{|l|l|l|l|}
\hline Site & Station & Latitude (South) & Longitude (East) \\
\hline \multirow{5}{*}{ Tudor } & Mikindani (Mik) & $4^{\circ} 41^{\prime \prime} 51^{\prime}$ & $39^{\circ} 21^{\prime \prime} 12^{\prime}$ \\
\cline { 2 - 4 } & English Point (Eng point) & $4^{\circ} 1^{\prime \prime} 34.7^{\prime}$ & $39^{\circ} 38^{\prime \prime} 47.5^{\prime}$ \\
\cline { 2 - 4 } & Fort Jesus (FJ) & $4^{\circ} 1^{\prime \prime} 29^{\prime}$ & $39^{\circ} 67^{\prime \prime} 96^{\prime}$ \\
\hline Port-Reitz & Makupa (Mak) & $4^{\circ} 2^{\prime \prime} 16.5^{\prime}$ & $39^{\circ} 38^{\prime} 50.1^{\prime}$ \\
\hline \multirow{3}{*}{ Mida } & Kirepwe & $3^{\circ} 3^{\prime \prime} 23.5^{\prime}$ & $39^{\circ} 48^{\prime \prime} 47^{\prime}$ \\
\cline { 2 - 4 } & Dabaso & $3^{\circ} 20^{\prime \prime} 39.8^{\prime}$ & $39^{\circ} 59.1^{\prime \prime} 2.8^{\prime}$ \\
\hline
\end{tabular}

The fish were sorted according to species and placed into ziploc bags that were labeled and then placed in cooler boxes with ice for transportation to the laboratory. In the laboratory, the fish were washed with distilled water, and rinsed in $70 \%$ ethanol to get rid of any particle affixed to the body surface. The fish samples were subdivided into three replicate groups of equal numbers based on species and location.Fish lengths $(\mathrm{cm})$ and weights $(\mathrm{g})$ were measured to the nearest $0.1 \mathrm{~mm}$ and $0.1 \mathrm{~g}$, respectively (Karami et al., 2017). The samples were wrapped in aluminum foil to avoid external contamination, placed in ziplocs and stored at $-40^{\circ} \mathrm{C}$ until further analyses.

\section{Processing and analysis of fish samples}

Sample processing and analysis were done at the Kenya Marine and Fisheries Research Institute (KMFRI) and the University of Nairobi (UON) Laboratories. The fins were chopped off and discarded. The fish were dissected by making a cut just below the throat and extending the cut down the ventral side to the anal pore (Gupta and Mullins, 2010). The gut, gills and the rest of the fish were separated into different samples, weighed, chopped into smaller pieces and digested using $10 \% \mathrm{KOH}$ (1g: 5 ml) (Foekema et al, 2013; Eriksen et al., 2013; Rochman et al., 2015; Dehaut et al., 2016; Kuhn et al., 2017; Thiele et al., 2019) at $60^{\circ} \mathrm{C}$ for 14 hours (modified protocol). Fins and bones did not digest completely and some organic matter was evident on samples of Rastrelliger kanagurta and Leptoscarus vaigiensis. Such samples were digested in $55 \%$ Nitric acid $\left(\mathrm{HNO}_{3}\right)$ solution $(10 \mathrm{~mL} / \mathrm{g})$ for a further five minutes to remove any organic material (Collard et $a l ., 2015)$. Acid digestion was done in a fume cupboard, in glass jars covered with watch glasses. The digestates were diluted by adding $100 \mathrm{~mL}$ of distilled water to protect the filtration equipment and ease floatation (Collard et al., 2015). The microplastic particles were density separated by adding filtered supersaturated Sodium Chloride $(\mathrm{NaCl})$ solution $\left(1.35 \mathrm{~g} \mathrm{~cm}^{-3}\right)$, in the ratio of 1: 3 (sample: salt solution), and left to settle overnight (12 hours) (Rochman et al., 2015; Kuhn et al., 2017 modified protocol). The supernatant was filtered by vacuum pump filtration over $0.8 \mu \mathrm{m}$ membrane filters. The filters with particles 
Microplastics contamination of fish from the Creeks along the Kenya coast, western Indian Ocean (WIO)

were placed in covered glass petridishes, and then dried at $40^{\circ} \mathrm{C}$ for 12 hours before being examined under a dissecting microscope at X40 magnification (Claessens et al, 2013; Lusher et al., 2013). Suspected microplastics were confirmed using the hot needle test (Witte et al, 2014; Devries et al, 2015), and further characterization done. The microplastics were characterized by shape and categorized as fiber, fragment or film and their color noted.

\section{Quality control}

Owing to the very light weight and mobility of Microplastics (MPs), caution was observed while analyzing samples toguarantee no contamination of samples by particles from the air. Sample processing and analyses were done in a clean room with no air flow (windows and doors shut) and limited human traffic. Samples were covered with aluminum foil and glass covers whenever not in use, while glassware and metal equipment were used. Equipments were rinsed with deionized water prior to use. Working surfaces were thoroughly cleaned using $70 \%$ ethanol three times and allowed to dry before use (Hidalgo-Ruzet al., 2012). Hand gloves were used and cotton laboratory coats were worn throughout. Long term blanks were measured (1 blank per sample analysis). A moistened filter paper $(30 \mathrm{~mm}$ diameter, Whatman No. 1) (Lusher et al., 2017) per sample was placed in a petri dish and left exposed during the processing and analysis period. A series of blanks set during the analyses process were examined for contamination.

\section{Data analysis}

Shapiro-Wilk's test was used to test data normality and all data was found to be normally distributed after log transformation. Species abundance and the mean concentrations of microplastics in species during the different seasons were compared using one- way ANOVA and the Turkey's post hoc test separated the means. One- way ANOVA was also used to compare the concentration of microplastics and the weight of tissues followed by a Turkey's test. A spearman's correlation was done to determine the relationship between the mean microplastic concentration and mean lengths and weights of the organisms. Species pairwise comparisons were done using Turkey's test. Fish data from the two seasons was combined for von Bertalanffy growth curves.

The assessment of MPs in the guts, gills and muscles was done in accordance with procedure and ethical guidelines for animal experiments in the University of Nairobi and KMFRI

\section{RESULTS \\ 1 Fish distribution and size}

A total of 225 specimens from five different species were obtained, most of which are benthic (Nelson, 1994: Sheaves, 2006: Fischer et al., 1990: Lieske and Myers, 2004; Froese and Pauly, 2020), and included Geres oyena (Forsskal, 1775), Acanthopagrus berda (Forsskal, 1775) and jarbua (Forsskal, 1775). Gerres oyena lives in coastal waters and is a carnivore (Cyrus and Blaber, 1982), Acanthopagrus berda (Forsskal, 1775) is predominantly marine (Nelson, 1994: Sheaves, 2006) with some living in euryhaline estuarine environments (Leu and Chou, 1996), and is an omnivore (Nasir, 2000: Shelta et al., 2018), Leptoscarus vaigiensis (Quay \& Galmard, 1824) is reef associated grazing fish (Locham et al., 2015) while, Rastrellige rkanagurta (Cuvier 1816) is pelagic and omnivore (Collette, 2001).

During the first sampling all five species were while in the second sampling only four species were encountered (due to absence of $L$. vaigiensis that had been 
Kerubo J.O. et al.

encountered at English point and was not encountered again) and all species were represented by fewer individuals. Mida and Tudor Creeks had a higher variety of fish species compared to Port-Reitz. In Mida this was mainly because of the high diversity encountered in Dabaso station while in Tudor all three stations sampled had different species. Gerres oyena was the most predominant species (91 individuals representing $44 \%$ ) and occurred in all stations except Fort Jesus and English Point (Table 2). Data on species diversity from the two sampling campaigns did not vary significantly (ANOVA: $\mathrm{F}=0.77$, df $=1, \mathrm{P}=$ 0.790). Although $G$. oyena was dominant, it did not occur in Port-Reitz Creek during the second sampling campaign.

The average $( \pm S E)$ weights and lengths of the different fish species showed wide ranges (Table 3) with the greatest mean weight range being observed in $G$. oyena perhaps because of its occurrence in different stations and seasons. The heaviest G. oyena individuals were encountered in Makupa followed by those from Dabaso while Mikindani had the smallest individuals. L. vaigiensis individuals were as heavy as the heaviest $G$. oyena individuals from Makupa while $A$. berda had the smallest individuals.

Table 2. Occurrence of different fish species in different sites and stationsof the Creeks along the Kenya coast, western Indian Ocean.

\begin{tabular}{|l|l|l|l|l|}
\hline Site & Station & Species & Jan 2018 & Sept 2018 \\
\hline \multirow{4}{*}{ Mida } & \multirow{2}{*}{ Dabaso } & G. Oyena & - & 16 \\
\cline { 3 - 5 } & & A. Berda & 31 & 9 \\
\cline { 3 - 5 } & & T. Jarbua & 37 & 6 \\
\hline \multirow{2}{*}{ Port-Reitz } & Kirepwe & G. Oyena & 15 & - \\
\hline \multirow{3}{*}{ Tudor } & Makupa & G. Oyena & 11 & - \\
\cline { 2 - 5 } & Mikindani & G. Oyena & 31 & 18 \\
\cline { 2 - 5 } & Fort Jesus & R. Kanagurta & 35 & 6 \\
\hline & English Point & L. Vaigiensis & 10 & - \\
\hline
\end{tabular}

Table 3. Mean $(( \pm S E)$ lengths and weights of fish of different species per site and station of the Creeks along the Kenya coast, western Indian Ocean.

\begin{tabular}{|c|c|c|c|c|c|c|}
\hline & & & Jan 2018 & & Sept 2018 & \\
\hline site & Station & Species & Av. Bw (g) & Av.TL $(\mathrm{cm})$ & Av. Bw (g) & Av. TL $(\mathrm{cm})$ \\
\hline \multirow{4}{*}{ Mida } & Dabaso & G. oyena & - & - & $79.9 \pm 0.1$ & $15.6 \pm 0.02$ \\
\hline & Dabaso & A. berda & $11.9 \pm 0.1$ & $9.7 \pm 0.03$ & $74.3 \pm 0.01$ & $9.8 \pm 0.01$ \\
\hline & Dabaso & T. jarbua & $16.3 \pm 0.17$ & $10.8 \pm 0.01$ & $74.8 \pm 0.1$ & $10.2 \pm 0.01$ \\
\hline & Kirepwe & G. oyena & $50.4 \pm 0.04$ & $14.9 \pm 0.1$ & - & - \\
\hline Port-Reitz & Makupa & G. oyena & $143.8 \pm 1.4$ & $28.2 \pm 0.06$ & - & - \\
\hline \multirow[b]{3}{*}{ Tudor } & Mikindani & G. oyena & $35.6 \pm 0.7$ & $12.8 \pm 0.2$ & $28.6 \pm 0.01$ & $19.4 \pm 0.03$ \\
\hline & Fort Jesus & R. kanagurta & $118.6 \pm 0.15$ & $22.3 \pm 0.08$ & $32.5 \pm 0.06$ & $10.3 \pm 0.1$ \\
\hline & English Point & L. vaigiensis & $143.1 \pm 0.74$ & $20 \pm 0.04$ & - & - \\
\hline
\end{tabular}

2.Length-weight relationship and Fish growth

The estimated $\mathrm{a}$ and $\mathrm{b}$ constants (Table 4) for G. oyena varied widely from those obtained by Kanak Tachihara (2006) who calculated the relationship as $\mathrm{W}=$ $0.0035 \mathrm{~L}^{2.89}$ for fish from Okinawa Island 
Microplastics contamination of fish from the Creeks along the Kenya coast, western Indian Ocean (WIO)

Japan, El Agamy (1988) W=0.00812L $\mathrm{L}^{3.13}$ for fish from the Arabian Gulf, and Letourneur et al., (1998) W=0.012L $\mathrm{L}^{3.232}$ for fish from New Caledonia. The mean b-value was low as all fish species except $A$. berda had negative allometry, hence did not obey the cubic law (Wootton, 2012). The growth of weight relative to length for A. berda was positively allometric showing that weight of fish increases lightly more than the cube of its length. The length-weight relationship for different investigated fish species was shown in Figure (2).

Table 4. Parameters of the Length-weight relationship for different fish species Creeks along the Kenya coast, western Indian Ocean.

\begin{tabular}{|l|l|l|r|r|r|l|}
\hline Species & Station & a-value & b-value & \multicolumn{1}{|c|}{$\mathrm{R}^{2}$} & $\mathrm{n}$ & Non-linear equation \\
\hline G. oyena & Dabaso & 3.1266 & 0.3675 & 0.4962 & 17 & $\mathrm{~W}=3.1266 \mathrm{~L}^{0.3675}$ \\
\hline G. oyena & Kirepwe & 4.2102 & 0.3275 & 0.8813 & 16 & $\mathrm{~W}=4.202 \mathrm{~L}^{0.3275}$ \\
\hline G. oyena & Makupa & 6.3678 & 0.3042 & 0.9796 & 12 & $\mathrm{~W}=6.3678 \mathrm{~L}^{0.3042}$ \\
\hline G. oyena & Mikindani & 11.631 & 0.0964 & 0.0127 & 46 & $\mathrm{~W}=11.631 \mathrm{~L}^{0.0964}$ \\
\hline R. kanagurta & Fort Jesus & 1.5434 & 1.3915 & 0.393 & 41 & $\mathrm{~W}=1.5434 \mathrm{~L}^{1.3915}$ \\
\hline A. berda & Dabaso & 0.0107 & 3.054 & 0.9143 & 40 & $\mathrm{~W}=0.0107 \mathrm{~L}^{3.054}$ \\
\hline T. jarbua & Dabaso & 0.1226 & 2.0467 & 0.4172 & 43 & $\mathrm{~W}=0.1226 \mathrm{~L}^{2.0467}$ \\
\hline L. vaigiensis & English Point & 0.0273 & 2.8453 & 0.9137 & 10 & $\mathrm{~W}=0.0273 \mathrm{~L}^{2.8453}$ \\
\hline
\end{tabular}

Y-intercept (a-value), slope of the curve (b-value) and the coefficient of determination $\left(\mathrm{R}^{2}\right)$

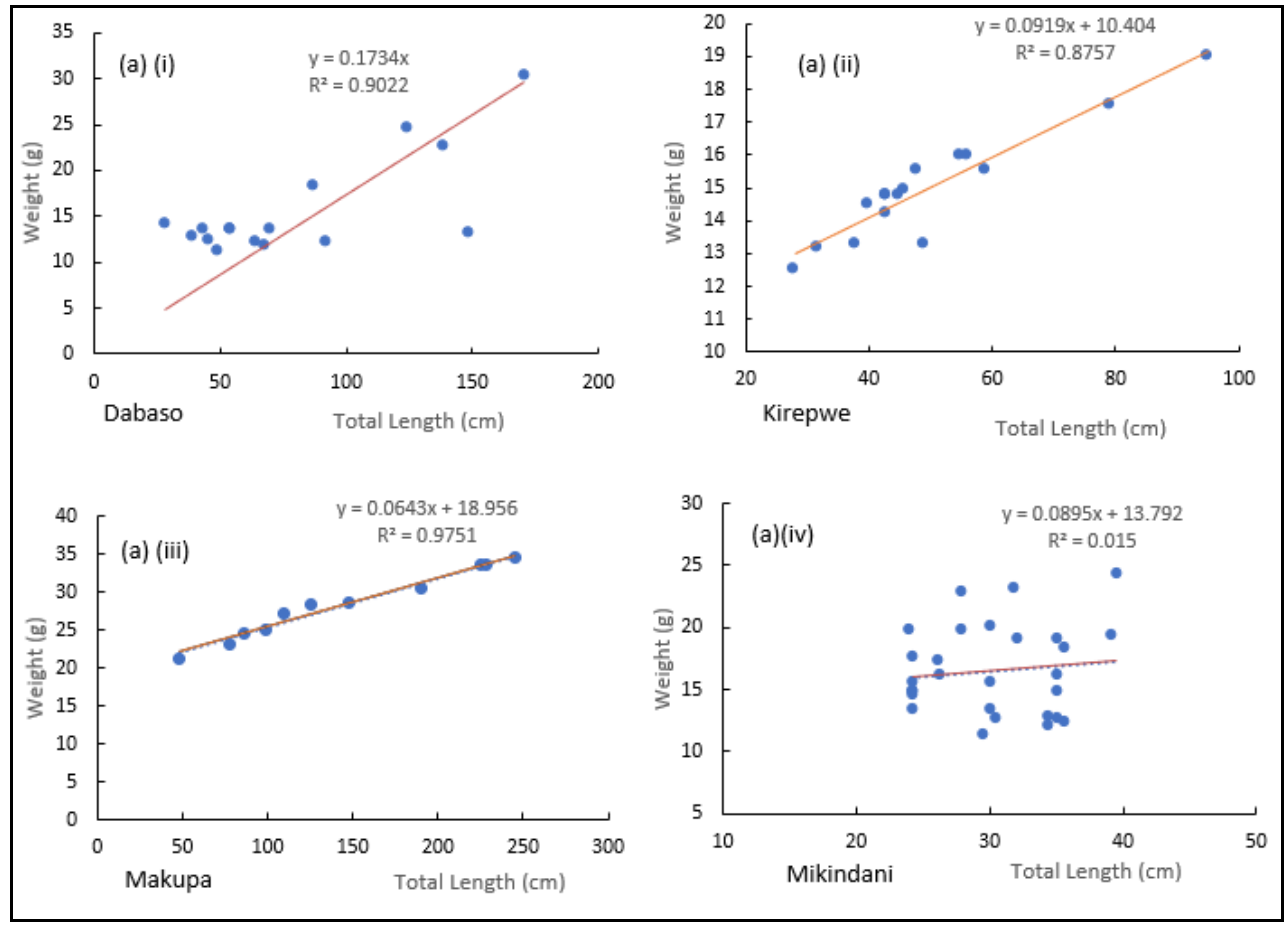

Fig. 2. The length-weight relationship for a) Gerres oyena, 
Kerubo J.O. et al.

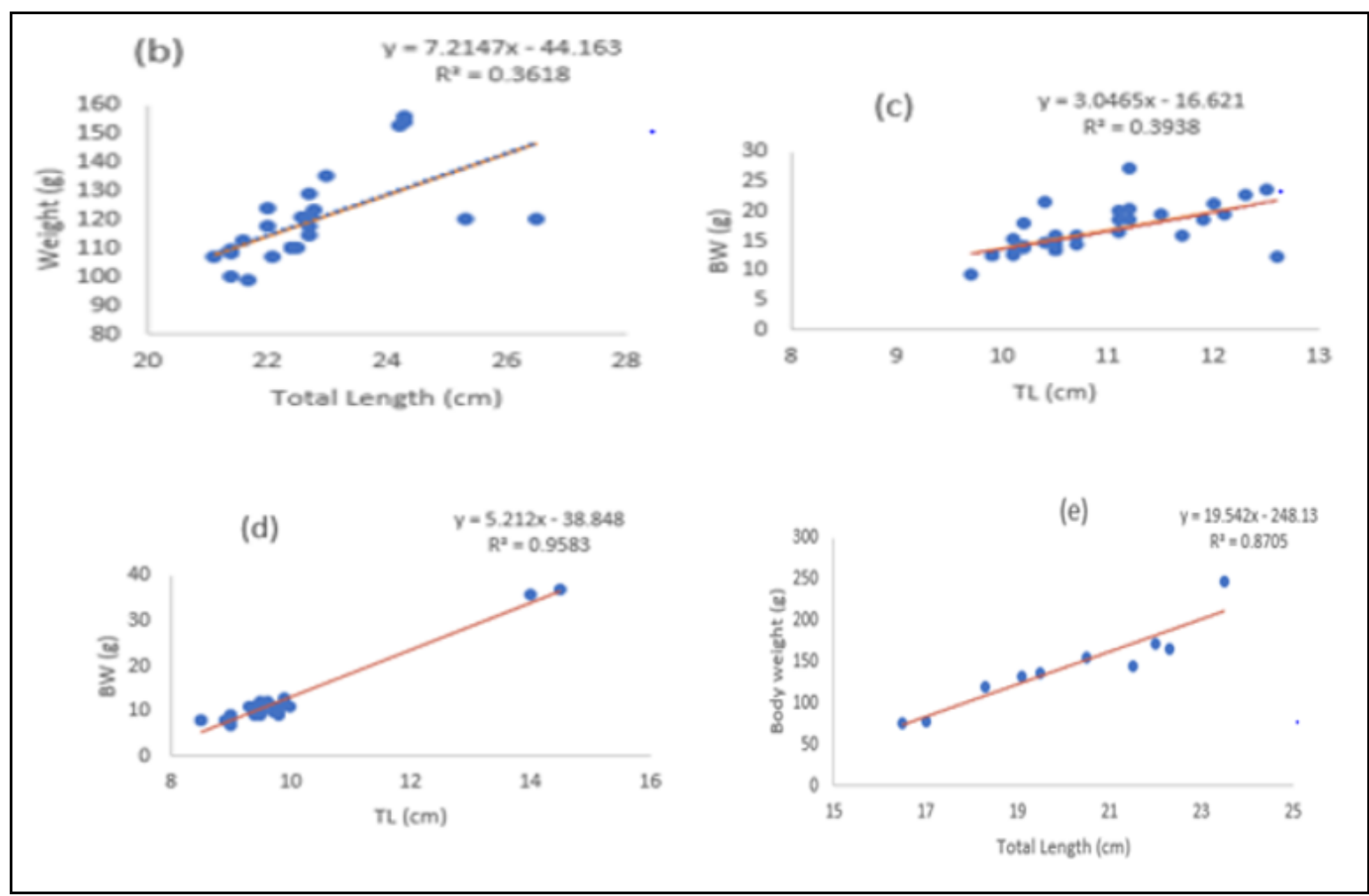

Fig. 2 (Cont.). The length-weight relationship b) Rastrelliger kanagurta, c)Terapon jarbua, d) Acanthopagrus berda, e) Leptoscarusvaigiensis from the creeks along the Kenya coast.

3. Overall mean concentration $\left(\mathrm{g}^{-1}\right)$ of microplastics in different fish species

The overall $( \pm \mathrm{SE})$ mean microplastics concentration in different species was below 1 microplastic per gram of tissue (Table 5) and was significantly different for $R$. kanagurta, T. jarbuaand $A$. berda ( $\mathrm{p}<0.05)$ between the first and second sampling periods.
Overall, the mean concentration of microplastics showed significant difference $(\mathrm{F}=12.69$, df $=11$, $\mathrm{p}<0.01)$ among species. Acanthopagrus berda from Mida had the highest mean concentration, while G. oyena from Mida and L. vaigiensis from, Tudor had the lowest mean concentration of microplastics per gram tissue.

Table 5. The concentration of MPs ( \pm ) in different fish species from different creeks and stations along the Kenya coast.

\begin{tabular}{|l|l|l|l|l|l|}
\hline Site & Station & Species & Jan 2018 & Sept 2018 & Mean conc \\
\hline Mida & Dabaso & G. oyena & - & $0.18 \pm 0.041$ & \\
\hline & & A. berda & $0.16 \pm 0.003$ & $0.52 \pm 0.01$ & $0.480 \pm 0.058$ \\
\hline & & T. jarbua & $0.15 \pm 0.008$ & $0.31 \pm 0.01$ & $0.240 \pm 0.04$ \\
\hline & Kirepwe & G. oyena & $0.041 \pm 0.032$ & - & \\
\hline Port-Reitz & Makupa & G. oyena & $0.1 \pm 0.034$ & - & \\
\hline Tudor & Mikindani & G. oyena & $0.2 \pm 0.02$ & $0.21 \pm 0.011$ & $0.209 \pm 0.051$ \\
\hline & Fort Jesus & R. kanagurta & $0.07 \pm 0.01$ & $0.16 \pm 0.004$ & $0.132 \pm 0.011$ \\
\hline & English Point & L. vaigiensis & $0.04 \pm 0.001$ & - & \\
\hline
\end{tabular}



Ocean (WIO)

Apairwise comparison in MPs concentration between different stations but the same sampling period, and same species but different sampling seasons produced varied results (Table 6). Significant differences $(p<0.05)$ were observed in the concentration of MPs in $G$. oyena between different stations during the same sampling season (Table 6).There was no significant difference in the concentration of MPs in $G$. oyena from Mikindani during the different sampling seasons $(\mathrm{t}=0.45, \mathrm{df}=2, \mathrm{p}=0.07)$. On the other hand, significant differences $(\mathrm{p}$ $<0.05)$ were observed in the concentration of MPs in all the other fish species between same species and different sampling seasons.

Table 6. Pairwise comparison of mean microplastic concentration $(X \pm S E)$ in fish

\begin{tabular}{|c|c|c|c|c|c|}
\hline Stations and seasons & Mean & Std. Err Mean & t- value & $\mathrm{df}$ & $\mathrm{P}$ \\
\hline \multicolumn{6}{|c|}{ Same species (Gerresoyena) } \\
\hline Jan - Sept Mik (same stn; diff sampling) & 0.014 & 0.031 & 0.45 & 2 & 0.70 \\
\hline Mik - Mak Jan (diff stn; same sampling) & 0.169 & 0.020 & 8.51 & 2 & 0.01 \\
\hline Mik - Kir Jan (diff stns; same sampling) & 0.159 & 0.029 & 5.55 & 2 & 0.03 \\
\hline Mik - Dab Sept (diff stn; same sampling) & 0.033 & 0.045 & 0.72 & 2 & 0.54 \\
\hline Kir Jan - Dab Sept (diff stns; diff sampling) & 0.141 & 0.056 & 2.50 & 2 & 0.13 \\
\hline \multicolumn{6}{|c|}{ Other species } \\
\hline R. kanagurta Jan -Sept (FJ) (diff sampling) & 0.408 & 0.153 & 7.62 & 2 & 0.012 \\
\hline A. berda Jan - Sept (Dab) (diff sampling) & 0.177 & 0.060 & 6.93 & 2 & 0.039 \\
\hline T.jarbua Jan - Sept (Dab) (diff sampling) & 0.036 & .012 & 5.98 & 2 & 0.040 \\
\hline
\end{tabular}

4-Concentration of microplastics in different fish species per gram tissue

Microplastics were observed in all investigated fish samples (Fig.3) with the benthic fish like $A$. berda $(0.480 \pm 0.058) G$. oyena and $T$. jarbua $(0.240 \pm 0.04)$ each having higher mean concentration compared to the pelagic, $R$. kanagurta $(0.132 \pm 0.011)$ and reef fish $L$. vaigiensis $(0.04 \pm$ 0.001),(Fig. 3) and the differences were significant $\left(\right.$ Chisq $\left._{4}=5504, \mathrm{p}=<0.01\right)$.

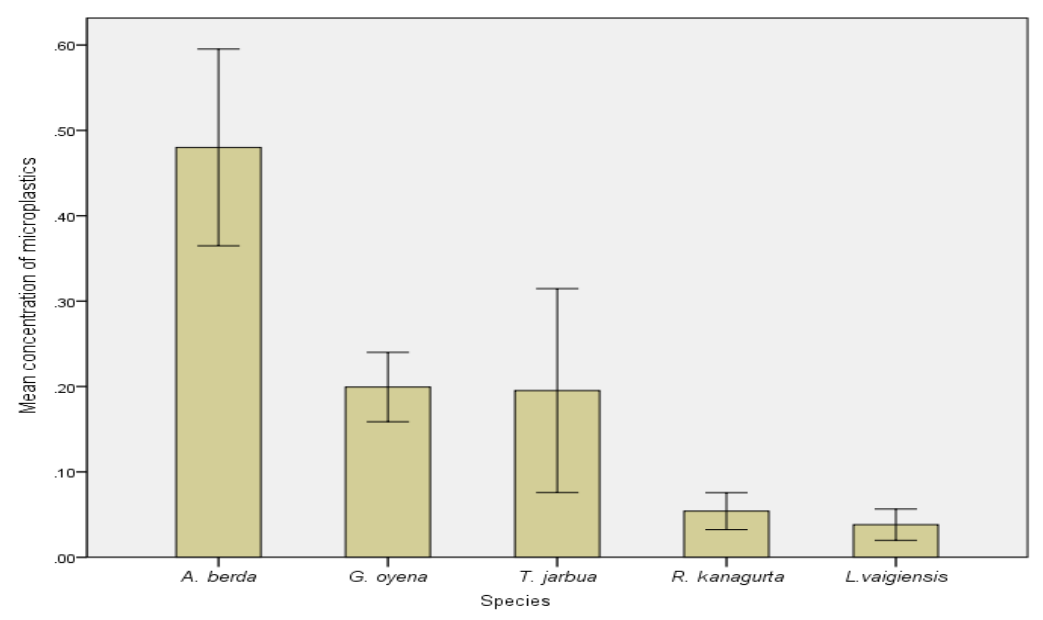

Fig. 3. Mean ( \pm SE) microplastics concentrations for the different fish species with standard error bars (MPs per gram). 
Kerubo J.O. et al.

A correlation between MPs with increase in body length (Fig. 4 a), while concentration and body length and weight showed that all fish species except $R$. kanarguta had increased MPs concentration

$G$. oyena and $L$. vaigiensis showed a decrease in MPs concentration with increase in body weight (Fig. 4 b).

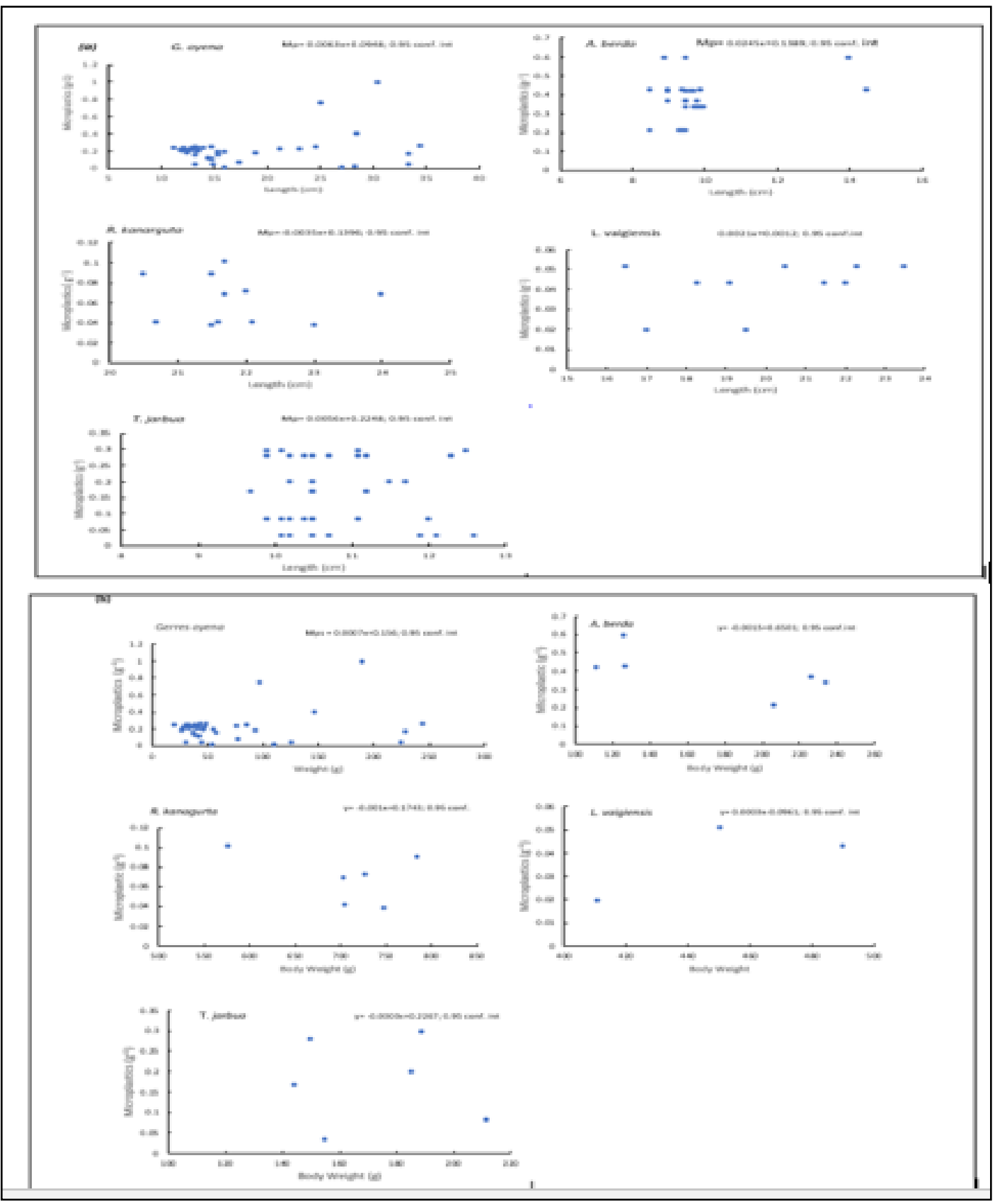

Fig. 4. Relationship between (a) MPs concentration and body length and (b) MPs concentration and body weight in the different species. 
5 Mean ( \pm SE) concentrations of microplastics in different organ tissues in different species

All the fish species contained microplastics in their guts, gills and body tissues (Table 7). There were significant differences $(\mathrm{F}=22.725, \mathrm{df}=20, \mathrm{p}=0.002)$ in the mean microplastic concentration in the guts between species. Guts of A. berda (7.41 \pm 0.42$)$ had significantly higher mean MPs concentration, compared to G. oyena, $R$. Kanxagurta, T. jarbua and $L$. vaigiensis but the latter three were not significantly different $(\mathrm{F}=1.549, \mathrm{df}=20, \mathrm{P}=0.211)$ (Table 7. With respect to the gills, A. berdaand $G$. oyena had significantly higher mean concentrations of MPs per gram tissue compared to other species but the two were not significantly different $(\mathrm{p}>0.05)$. Generally, the mean concentrations of MPs in the rest of the fish body were lower than $0.1 \mathrm{MPs} \mathrm{g}^{-1}$ across all species and stations.

Based on station, the guts of $G$. oyena from Dabaso had a significantly higher $(\mathrm{F}=12.692, \mathrm{df}=7, \mathrm{p}<0.05)$ mean concentration $\left(\mathrm{g}^{-1}\right)$ of microplastics compared to those from Kirepwe, Mikindani and Makupa but the latter three were not significantly different $(\mathrm{p}>0.05)$. Similarly, the gills of G. oyena from Dabaso had a significantly higher mean concentration of MPs $\left(\mathrm{g}^{-1}\right)(\mathrm{F}=13.142, \mathrm{df}=7, \mathrm{p}=0.001)$ compared to other stations (Table 7).

Table 7 Mean $(x \pm S E)$ concentration of microplastics in various organs per gram tissue of the different fish species

\begin{tabular}{|l|l|l|l|l|l|l|}
\hline \multirow{2}{*}{ Site } & & & \multicolumn{4}{|l|}{ Microplastics in organs $\mathbf{~}^{-1}$} \\
\cline { 4 - 7 } & Station & Species & \multirow{2}{*}{ MPs g $^{-1}$} & Guts & Gills & Body \\
\hline Mida & Dabaso & G. oyena & $0.181 \pm 0.041$ & $* 3.557 \pm 0.15$ & $* 2.599 \pm 0.23$ & $0.042 \pm 0.001$ \\
Tudor & Kirepwe & G. oyena & $0.041 \pm 0.032$ & $1.398 \pm 0.05$ & $1.339 \pm 0.07$ & $0.004 \pm 0.001$ \\
Port-Reitz & Mikindani & G. oyena & $0.209 \pm 0.051$ & $1.43 \pm 0.02$ & $0.172 \pm 0.05$ & $0.015 \pm 0.001$ \\
Tudor & Makupa & G. oyena & $0.1 \pm 0.034$ & $0.94 \pm 0.01$ & $1.92 \pm 0.12$ & $0.02 \pm 0.0$ \\
Tudor & Fort Jesus & R. Kanagurta & $0.132 \pm 0.011$ & $1.44 \pm 0.03$ & $0.74 \pm 0.01$ & $0.01 \pm 0.01$ \\
Mida & English Point & L. vaigiensis & $0.04 \pm 0.001$ & $0.56 \pm 0.1$ & $0.45 \pm 0.1$ & $0.01 \pm 0.01$ \\
Mida & Dabaso & A. berda & $0.48 \pm 0.058$ & $* 7.41 \pm 0.42$ & $* 2.82 \pm 0.08$ & $0.081 \pm 0.01$ \\
\hline
\end{tabular}

$*$ indicates high concentration of microplastics

6- Microplastic types by shape and colour in the tissues of different fish species

Most of the MPs recovered from the fish were fibers $(91.4 \%)$ and a small percentage (8.6\%) were fragments (Fig. 4). Similarly, significantly higher $(\mathrm{F}=22.721$, $\mathrm{df}=20, \mathrm{P}<0.001)$ proportions of fibers were observed in fish gills, compared to fibers in guts, and in fish body (Fig 5). In addition, clear balls of fibers were observed in the guts of some fish of R. kanagurta and G. oyena species (Fig. 6). 
Kerubo J.O. et al.

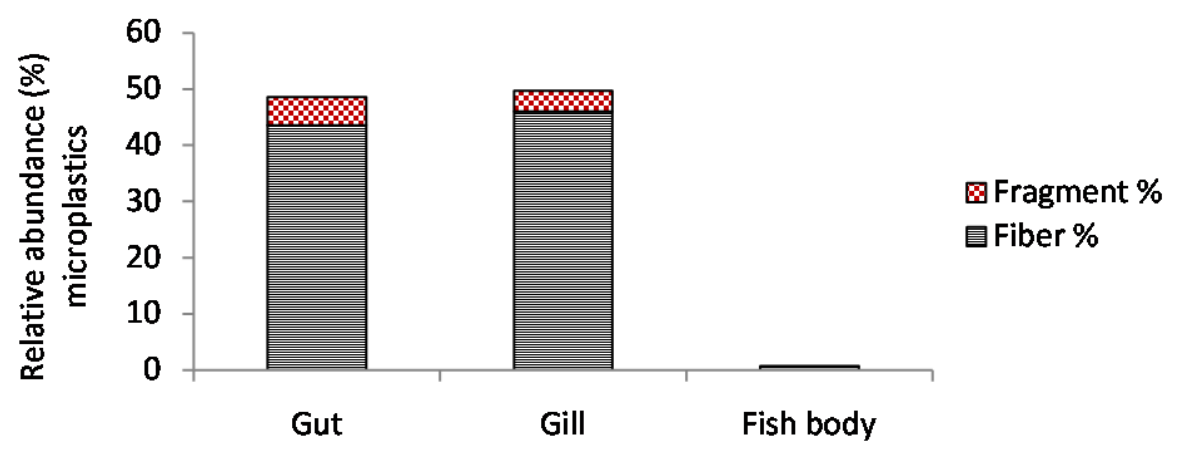

Fig. 5. Mean percentage concentration of microplastic shapes observed in organs of different fish species from the creeks along the Kenya coast.
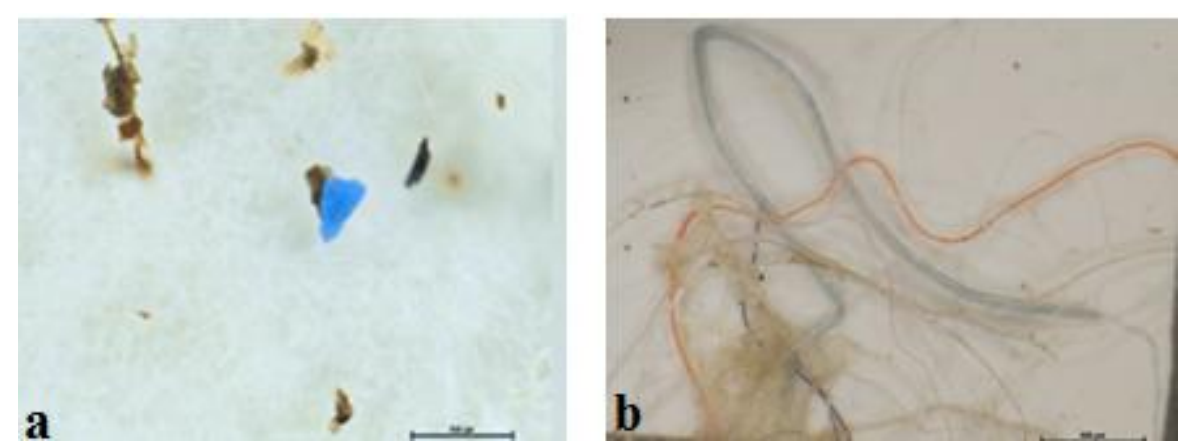

Fig. 6.Examples of microplastic types by shape recovered from fish tissues: (a) Blue fragment from the gut of $\boldsymbol{R}$. kanagurta of Fort Jesus (b) Red, blue and black tangled fibers from the gills of $G$. oyena of Makupa

The majority of the microplastics were blue $(36.4 \%)$ and black $(34.2 \%)$

followed by white (18.4\%), green $(6.5 \%)$, red $3.3 \%)$, and purple (0.9\%) (Fig.7).

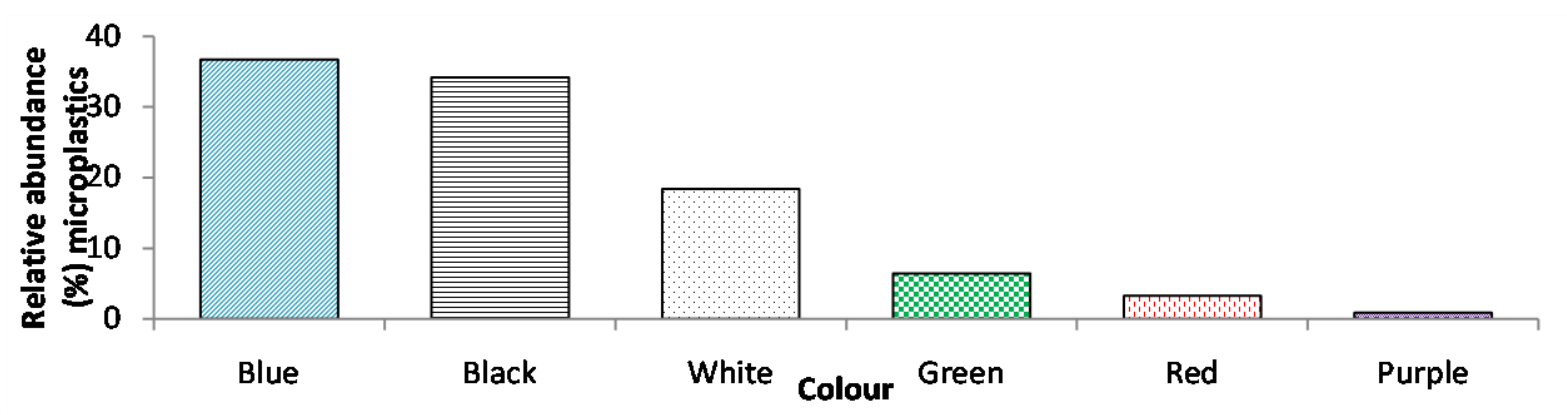

Fig. 7. Mean percentage concentration of microplastic colours observed in different fish species from the creeks along the Kenya coast 


\section{DISCUSSION}

Kosore et al. (2018), Awour et al., (2020) and Kerubo et al. (2020; 2021) distinctly showed that microplastics were abundant in the Kenya's marine environments and are interacting with zooplankton and macro-invertebrates by way of ingestion. Fish are economically important as human food (Barboza, et al., 2018). Some of the risks associated with marine fish are the incorporation of microplastics and adsorbed chemicals into the food web through trophic transfer (Setälä et al., 2018). Ingestion of microplastics increases toxicity of plastic chemicals such as nonylphenols, bisphenol A and antioxidants in the organisms through leaching (Hermabessiere et al., 2017). It is therefore imperative to assess the interaction of microplastics in marine fish, as a potential risk to humans. The present study focused on the sites around Mombasa due to the rapid increase in human population and high solid wastes from tourism and industrial sectors (Okuku, 2019). Microplastics are present everywhere including Dabaso within Watamu Marine National Park, a protected area expected to be free from microplastic contamination (Kerubo et al, 2020; 2021).

Growth in fish is isometric if body weight increases with increase in total body length $(b=3)$, positively allometric if the $b$ value is greater than 3 and negatively allometric if the b-value is far less than 3 (Ricker, 1975; Wootton, 2012). Based on Fish Base data, different fish species attain maturity at different body lengths; $G$. oyena attains maturity at an average total body length of $22 \mathrm{~cm}$ (Roux, 1986), T. jarbua 13 $\mathrm{cm}$ (Lieske and Myers, 1994), A. berda 20$22 \mathrm{~cm}$ (Smith and Smith, 1986), $R$. kanagurta $19.9 \mathrm{~cm}$ (Sommer et al., 1996) and $L$. vaigiensis at $16.5-18.4 \mathrm{~cm}$ total body length for fish in parks and reserves and attains a maximum body length of $35 \mathrm{~cm}$
(Randall, 1986). In this study, the collected samples of G. oyena, from Makupa could be considered mature, while the rest of the fish sampled were immature. The length-weight relationship gave a good fit to the length and weight of A. berda (James et al., 2003; Ontomwa et al., 2018), while data for the length-weight relationship for other fish species did not. The length-weight relationships for $A$. berda, indicates isometric allometry, an indication that the species had homogenous groups in their populations with body weights varying independently with the cube of the total length. The high coefficient of determination implied proportional increase in weight and length. These results affirm earlier research on A. berda from the North Coast of Kenya, $\left(\mathrm{W}=0.0191 \mathrm{~L}^{2.988}\right)$ with a coefficient determination $\left(\mathrm{R}^{2}=0.9676\right)$ (Anam et al., 2019) and from Shimoni artisanal fishery, Kenya (Ontomwa et al., 2018). The lengthweight relationship of $A$. berda could have influenced microplastic ingestion during feeding. Isometric growth could be attributed to the phenotype of the species, condition of the fish, the environment and food availability (Ontomwa et al., 2018; Anam et al., 2019).

The length-weight relationship for $G$. oyena and $L$. vaingiesis imply positive correlation and negative allometric growth, while the length-weight relationships for $R$. kanagurta, and T. jarbua indicate negative correlation and negative allometric growth patterns. Negative allometry indicates that the species had heterogenous groups with body weights varying differently with the cube of total length. Such growth could be attributed to feeding and spawning biological aspects which have much impact on the length- weight relationships. These results contrast previous research results for G. oyena from the Gulf of Suez, W= $0.094 \mathrm{~L}^{3.11}$ (Saber et al., 2020), and from 
Kerubo J.O. et al.

Caledonia (W=0.0120 L $\mathrm{L}^{3.232}$ ) (Letourneur et al., 1998) but agree with results for $G$. oyena from Okinawa Island Southern Japan, W= $0.035 \mathrm{~L}^{2.89}$ (Kanak and Tachihira, 2006), $T$. jarbua from Mindano, Philippines, $\mathrm{W}=$ $0.0006 \mathrm{~L}^{2.8484}$ (Fortaleza et al., 2019) and $L$. vaigiensis from Shimoni artisanal Fishery, Kenya, W $=0.0000129 \mathrm{~L}^{2.3}$ (Ontomwa et al., 2018), showing that length of fish increased more than weight. The results also contrast results of $R$. kanagurta from Mangalore India, $\mathrm{W}=0.0045 \mathrm{~L}^{3.2234}$ (Hulkot et al., 2013), which indicate positive correlation and allometry. The negative allometric growth could be attributed to several factors including insufficient feeding, age, sex, health condition of the fish, poor food quality and availability, low salinities and poor habitat conditions (Sarre and Potter, 2000; Froese, 2006).

This study established that fish within the Creeks along the Kenya coast are contaminated with microplastics, including those from Mida Creek which was expected to be free of microplastic contamination. Significant variations in microplastic concentrations among species could be explained by differences in habitats and feeding behaviour that affect ingestion of microplastics. For example, $A$. berda is demersal and feeds on benthic invertebrates mainly barnacles, crabs and oysters, (Fischer et al., 1990) known to ingest and accumulate microplastics (Neves et al., 2015; Li et al., 2016; Nelms et al., 2018; Awour, 2020) hence the high microplastics in the species. Geres oyena was the most abundant and widespread species in the investigated sites. It is demersal species that inhabiting inshore areas and feeds on small organisms and benthic invertebrates living in sandy bottoms (Lieske and Myers, 2004; Froese and Pauly, 2020), while $T$. jarbua is demersal feeding mainly on white (Paneaus indica) and brown (Paneaus monoceros) shrimps and on small fishes which may accumulate MPs and pass them on to a higher trophic predator. Rastrelliger kanagurta is pelagic and omnivore, feeding on algal materials and small invertebrates (Collette, 2001), while L. vaigiensis, is pelagic, reef associated inhabiting seagrass areas and is herbivorous feeding on sea grasses and algae (Sommer, 1996; Locham et al., 2015; Froese and Pauly, 2017). MPs are likely to arrive into the coastal environment through rivers and may have high concentration in the surface waters (Kerubo et al., 2020), yet pelagic fish tend to accumulate much less compared to the demersal fish.

Small invertebrates accumulate microplastics passing them up trophic levels, thereby increasing microplastics in higher trophic levels (GESAMP, 2016) as was the case with A.berdaand G. oyena. The high contamination with MPs of $A$. berda from Dabaso both in the gut and gills could not be explained as it was not the site with the highest MPs concentration in the surface water and the sediments (Keruboet al, 2020; 2021) although Awuor et al, (2020) found that MPs concentrations in the invertebrates in Dabaso were comparable to other sites along the Kenya Coast. On the contrary, Mikindani had recorded relatively high MPs in the sediments (Kerubo et al., 2021) and $G$. oyena population from that site had not accumulated as high MPs in the gut and gills as was observed in the population from Dabaso. This suggests that several factors playing together influence MPs contamination in fish and not just the level of contamination of the environment.

Leptoscarus vaigiensis from English

Point had the lowest microplastic concentrations in the gut and gills which could be as a result of the fish not spending much time in the creeks being reef associated species and only occasionally venturing into the creeks (Locham et al, 2015). This could imply that the reefs are 


\section{Microplastics contamination of fish from the Creeks along the Kenya coast, western Indian} Ocean (WIO)

less contaminated with MPs compared to the creeks. The current results are consistent with earlier research where similar concentrations have been observed in the digestive tracts of the Mediterranean lantern fishes which are both shallow and deperliving but pelagic feeders, mainly feeding on mesopelagic fish (Romeo et al., 2016)and the South African catfish which is omnivore with carnivorous tendency (Silva-Canti et al., 2017), but were lower than those obtained in the gastrointestinal tracts of fish from other regions of the world, such as crevalle jack (Caranix hippos, Linnaeus, 1766) (Froese and Pauly, 2017). The relatively high microplastic concentrations in both juvenile and mature fish samples indicates that size or age does not influence microplastic ingestion in fish.

Microplastic concentrations were significantly lower in fish body tissues but significantly higher in the guts and gills of all the fish species. The low microplastic concentration in the fish body could be attributed to the total weight due to inclusion of bones and fins. The high concentration of microplastics in the guts and gills of $A$. berda and $G$. oyena from Dabaso could imply transfer of the contaminants to humans in high concentrations if the fish is consumed whole. For example, in this study, consuming $1 \mathrm{~kg}$ whole $A$. berda from Dabaso could transfer as much as $1031 \pm$ 0.42 microplastics, while the same quantity of gutted fish with gills discarded would transfer about $81 \pm 0.02$ MPs particles only.

Microplastics were mainly fibers agreeing with earlier research by Nelms et al. (2018), reporting similar results in the Atlantic Mackerel with fibers (72\%) being higher than fragments (Nelms, 2018), as well as in the digestive tracts of the South African catfish (Silva-Cantiet al., 2017). Fibers made up $88 \%$ of the microplastics in five fish species in China (Jabeen et al. 2017), $96 \%$ of microplastics in fish from
Texas (Fazey and Ryan, 2016) and were predominant in the stomachs of Mediterranean lantern fishes (Romeo et al., 2016) among others. The occurrence of clear balls of fibers in guts of some fish is consistent with earlier research reports of bunched balls of microplastics in the digestive tract of the Lates niloticus (Linnaeus, 1758) and the Oreochromis niloticus (Linnaeus, 1758) in Lake Victoria (Biginagwa et al, 2016).

The high percentage of fibers suggests waste water treatment, domestic waste water, fishing ropes and nets, degraded plastic bags, synthetic textiles and tourism activities could be the main sources of microplastics (Khan et al., 2018; Graca et al., 2017). The presence of film fragments suggests light weight plastics could be the source. It is worthwhile to note that the source of microplastics directly influences their concentration in water bodies and subsequently fishes (Free et al., 2014).

Most of the microplastic particles from fish in this study were blue and black. Earlier research reported red, blue, and white elongated fibers in the Gulf of Mexico with no proportions (Philips, 2015). Variations in microplastic particle colours implied multiple sources of the pollutants. Further investigation is required to establish the source of microplastics in the demersal and pelagic fishes of the creeks along the Kenya Coast and the subsequent impact on human health.

\section{Conclusions}

The study established that both demersal and pelagic fish ingest microplastics and body size or age did not influence their ingestion. Growth of the fish species in the study deviated from the norm in literature for the same species which could probably suggest that fish are affected by microplastics in the aquatic environment. Although all the fish species had 
Kerubo J.O. et al.

microplastics in their guts, gills and the rest of the body, fish body had significantly lower values than the gut and gills. But the fact that microplastics are found in the fish body tissue is alarming as it demonstrates gut tissue or gill tissue transfer of microplastics.

In retrospect, this study shows that common fish in the creeks along the Kenya coast ingesting microplastics could pose a risk to humans especially if they are consumed whole.

Microplastics of different shapes and colours were ingested most of which blue were indicating multiple sources of these pollutants. High microplastic concentrations in demersal and pelagic fish indicate that microplastics in the creeks along the Kenya coast accumulate in sediments and the water column and differences in feeding modes influence ingestion.

This study has implications for fishery and wildlife management. Understanding of the results could benefit the National and International Governments, environmental advocacy groups such as NEMA, and Intergovernmental organizations. Moreover, this study supports the February 2017 ban on production, and use of light weight plastics by the Kenya government as there were both fiber and film particles found in the study.

\section{Recommendation}

It is more safely to remove gut and gills from all fish regardless of their size before being processed or cooked for human consumption.Research is needed to determine the source of microplastics. It is necessary to compel more effective actions and mitigations for plastic waste management to reduce the microplastic numbers in the oceans.

\section{Acknowledgements}

The authors wish to thank the Director KMFRI for allowing the use of institutional facilities, the UON and KMFRI technical staff and David Gitahi for his assistance.

\section{Funding}

This research was funded by the NRF, NACOSTI/STI/KE-SAgrant number /5/003.

\section{REFERENCES}

Anam, R.O.; Munga, C.N. and Gonda, J.R. (2019). The biology of Goldsilk Sea Bream (family: Sparidae) from the inshore waters of north coast Kenya. Western Indian Ocean J.Mar. Sci., 18(2): 77-86.

Andrady, A.L.(2011). Microplastics in the marine environment. Mar. Pollut. Bull., 62: 1596-1605. PMID: 21742351. doi:10.1016/j.marpolbul.2011.05.030.

Awuor, W.; Muthumbi, A.W.N. and Robertson - Andersson, D.V. (2020). Presence of microplastics in benthic macroinvertebrates along the Kenyan coast, Afr. J. Mar. Sci., 42:4, 405-411. doi: 10.2989/ 1814232X.2020.1829045

Barnes, D.K.A.; Galgani F.; Thompson, R.C. and Barlaz, M. (2009). Accumulation and fragmentation of plastic debris in global environments. Philosophical Transactions Royal Soc. B, 364:1985-1998.

Barboza, L.G.A.; Vethaak, A.D.; Lavorante, B.R.; Lundebye, A.K. and Guilhermino, L. (2018). Marine microplastic debris: An emerging issue for food security, food safety and human health. Mar. Pollut. Bull., 133: 336-348

Beer, S.; Garm, A.; Huwer, B.; Dierking, J. and Nielsen, T.G. (2018). No increase in marine microplastic concentration over the last three decades- A case study from the Baltic Sea. Sci. Total Environ., 621: 1272-1279. 
Microplastics contamination of fish from the Creeks along the Kenya coast, western Indian Ocean (WIO)

Biginagwa, F.J.;Mayomaa, B.S.;Shashouad, Y.;Syberga, K. and Khan, F.R., (2016). Firstevidence of microplastics in the African Great Lakes: recovery from Lake Victoria Nile perch and Nile tilapia. J. Great Lakes Res., 42:146-149. doi:10.1016/j.jglr.2015.10.012.

Claessens, M.; Van Cauwenberghe, L.; Vandegehuchte, M.B. and Janssen, C.R. (2013). Newtechniques for the detection of microplastics in sediments and field collected organisms. Mar. Pollut. Bull., 70 (12):227-233.

Collard. F.; Gilbert, B.; Eppe, G.; Parmentier, E. and Das, K. (2015). Detection of anthropogenic particles in fish stomachs: an isolation method adapted to identification by Raman spectroscopy. Arch. Environ. Contamin. Toxicol., 69: 331-339. PMID: 26289815. doi:10.1007/ s00244-015-0221-0.

Cole, M.; Lindeque, P.; Fileman, E.; Halsband, C.; Goodhead, R.; Moger, J. and Galloway, T.S.(2013). Microplastic ingestion by zooplankton. Environ. Sci. Technol., 47 (12): 6646-6655.

Cole, M.; Lindeque, P.; Fileman, E.; Halsband, C. and Galloway, T.S., (2015). The Impact of polystyrene microplastics on feeding, function and fecundity in the marine copepod Calanus helgolandicus. Environ. Sci. Technol., 49:1130-1137.

Collette, B.B. (2001). Tunas (also, Albacore, Bonitos, Mackerels, Seer fishes and Wahoo). FAO Species Identification Guide for Fishery Purposes: The Living Marine Resources of the Western Central Pacific, Carpenter, $\mathrm{KE}$ and V. Niem (Eds.). Food and Agricultural Organization, Rome, 3721-3756.
Dehaut, A.; Cassone, A-L.; Frère, L.;Hermabessiere, L.; Himber, C.;Rinnert, E.; Rivière, G.; Lambert, C.;Soudant, P.;Huvet, A.;Duflos, G. and Paul-Pont, I. (2016). Microplastics in seafood: Benchmark protocol for their extraction and characterization. Environ. Pollut., 215: 223- 233.

Devriese, L.I.; Van De Meulen, M.M.; Maes, T.; Bekaer, T.K.; Paul-Pont, I.; Frere, L.; Rubbens, J. and Vethaak, A.D. (2015). Microplastic contamination in brown shrimp (Crangon crangon, Linneus 1758) from the coastal waters of the Southern North Sea and channel area. Mar. Pollut. Bull., 98: 179-187.

De Witte, B.; Devriese, L.; Bekaert, K.; Hoffman, S.; Vandermeersch, G.; Cooreman, K. and Robbens, K., (2014). Quality assessment of the blue mussel (Mytilus edulis): Comparison between commercial and wild types. Mar. Pollut. Bull., 85(1):146-155. DOI: $10.1016 / \mathrm{j}$. marpolbul.2014.06.006.

Eerkes-Medrano, D.; Thompson, R.C. and Aldridge, D.C., (2015). Microplastics in freshwatersystems: a review of the emerging threats, identification of knowledge gaps and prioritization of research needs. Water Res., 75: 63-82. PMID: 25746963 . doi:10.1016/j.watres. 2015.02.012.

Eriksen, M.; Mason, S.; Wilson, S.; Box, C.; Zellers, A.; Edwards, W.; et al (2013). Microplastic pollution in the surface waters of the Laurentian Great Lakes. Mar. Pollut. Bull., 77:177-182.

Fazey, F.M.C. and Ryan, P.G., (2016). Biofouling on buoyant marine plastics: an experimental study into the effect of size on surface 
Kerubo J.O. et al.

longevity. Environ. Pollut., 210:

354-360. PMID: 26803792.

doi:10.1016/j.envpol.2016.01.026.

Farrell, P. and Nelson, K. (2013). Trophic level transfer of microplastic: Mytilus edulis (L.) to Carcinus maenas (L.). Environ. Pollut., 177:1-3. https://doi.org/ 10.1016/j.envpol.2013. 01.046.

Foekema, E.M.; De Gruijter, C.; Mergia, M.T.; Van Franeker, J.A.;. Murk, A.J. and Koelmans,A.A. (2013).Plastic in North Sea fish. Environ. Sci. Technol., 47 (15): 8818-8824.

Fortaleza, M.A.; Uy, R.C.L.; Elumba, M.E. andNañola, C.L. (2019). Age-growth parameters of Crescent grunter, Terapon jarbua (Forsskål, 1775) in Mindanao, Philippines. Philippine J. Nat. Sci., 24: 42-49.

Free, C.; Jensen, O.; Mason, S.; Eriksen, M.; Williamson, N. and Boldgiv, B. (2014). High-levels of microplastic pollution in a large, remote, mountain lake. Mar. Pollut. Bull., 85: 156-163. PMID: 24973278. doi:10.1016/j.marpolbul.2014.06.001

Faroese, R. (2006). Cube law, condition factor and weight-length relationships: History, meta-analysis and recommendations. J. Appl. Ichthyol., 22: 241-253

Froese, R. and Pauly, D. (Editors). (2017). FishBase. World Wide Web electronic publication. http://www. fishbase.org (02/ 2017)

Froese, R. and Pauly, D. (eds.) (2020). Fishbase. World Wide Web electronic publication. www. fishbase.org, (2/2020).

GESAMP (2016). Joint Group of Experts on the Scientific Aspects of Marine Environmental Protection. Sources, fate and effects of microplastics in the marine environment: part 2 of a global assessment. Reports Stud. GESAMP [Internet]. 93:96. At: http://ec.europa.eu/environment/marine/ good-environmental-status/descriptor10/pdf/GESAMP_microplasticsfullstudy .pdf

Graca, B.;Szewc, K.; Zakrzewska, D.; Dołęga, A. and SzczerbowskaBoruchowska, M. (2017). Sources and fate of microplastics in marine and beach sediments of the Southern Baltic Sea. A preliminary study. Environ Sci. Pollut. Res., 24: 76507661.

Gupta, T. and Mullins, M.C. (2010). Dissection of organs from the adult zebra fish. J. Visualized Experm., (37): e1717.

Hable, W.E. and Nguyen, X. (2013). Polychlorinated biphenyls disrupt cell division and tip growth in two species of fucoid algae. J. Phycol., 49(4): 701-708.

Hartline, N.L.; Bruce, N.J.; Karba, S.N.; Ruff, E.O.; Sonar, S.U. and Holden, P.A. (2016). Microfiber masses recovered from conventional machine washing of new or aged garments. Environ. Sci. Technol., 50: 11532-11538. PMID: 27689236. doi:10.1021/acs.est.6b03045.

Hermabessiere, L.; Dehaut, A.; Paul-Pont, I.; Lacroix, C.; Jezequel, R.; Soudant, P. and Duflos, G. (2017). Occurrence and effects of plastic additives on marine environments and organisms: a review. Chemosphere, 182: 718-793

Hidalgo-Ruz, V.; Gutow, L.; Thompson, R.C. and Thiel, M. (2012). Microplastics in the marine environment: a review of the methods used for identification and quantification. Environ. Sci. Technol., 46 (6): 3060-307

Hong, S.H.; Shim, W.J. and Jang, M. (2018). Chemicals associated with 
Microplastics contamination of fish from the Creeks along the Kenya coast, western Indian Ocean (WIO)

marine plastic debris and microplastics: Analyses and contaminant levels. In: Microplastic Contamination in Aquatic Environments, 271-315.

Hulkoti, S.H.; Shivaprakash, S.; Anjanayappa, H.N.; Somashekara, S.R.; Benakappa, S.; Naik, A. K. and Kumar, J. (2013). Length-weight relationship of Rastrelliger kanagurta (Cuvier) from Mangalore region. Environ. Ecol., 31(2A), 676678.

Jabeen, K;, Su, L.; Li, J.; Yang, D.; Tong, C. and $\mathrm{Mu}$, J. (2017). Microplastics and mesoplastics in fish from coastal and fresh waters of China. Environ. Pollut., 221: 141-149. PMID: 27939629. doi:10.1016/j.envpol. 2016.11.055.

James, N.C.; Mann, B.Q.; Beckley, L.E. and Govender, A. (2003). Age and growth of the estuarine-dependent sparid Acanthopagrus berda in northern KwaZulu-Natal, South Africa. Afr. Zool., 38(2): 265-271.

Kanak, M.K. andTachihara, K. (2006). Age and growth of Gerres sp. (Perciformes: Gerreidae) in Okinawa Island of southern Japan. Fisher. Sci., 72(5): 932-938.

Karami, A.; Golieskardi, A.; Choo, C.K.; Romano, N.; Ho, Y.B. and Salamatinia, B. (2017). A highperformance protocol for extraction of microplastics in fish. Sci.Total Environ., 578: 485-494.

Karlsson, T.M.; Vethaak, A.D.; Almroth, B.C.; Ariese, F.; van Velzen, M.; Hassellöv, M. And Leslie, H.A. (2017). Screening for microplastics in sediment, water, marine invertebrates and fish: method development and microplastic accumulation. Mar. Pollut. Bull., 122(1-2): 403-408.
Kerubo, J.O.; Muthumbi, A.W.; Onyari, J.M.; Kimani, E.N. and RobertsonAndersson, D. (2020). Microplastic pollution in the surface waters of creeks along the Kenyan coast, Western Indian Ocean (WIO). Western Indian Ocean J. Mar. Sci., 19(2): 75-88.

Kerubo, J.O.; Muthumbi, A.W.N.; Onyari, J.M.; Robertson-Andersson, D. and Kimani, E. (2021). Microplastics pollution in the sediments of creeks and estuaries of Kenya, western Indian Ocean. Afr. J. Mar. Sci., 43(3) 337-352.

Khan, F.R.; Mayoma, B.S.; Biginagwa, F.J. and Syberg, K. (2018). Microplastics in inland African waters: Presence, sources, and fate. In: Freshwater microplastics (pp.101-124). Springer, Cham.

Kitheka, J.U.; Okemwa, E.N. and Kazungu, J.M., (1999). Monitoring of nutrient levels, turbidity

and sediment transport at Port-Reitz Creek in Kenya. IOC-SIDA GIPME/MARPOLMON nutrients, sediment transport and turbidity monitoring programme, Report.

Koelmans, A.A.; Besseling, E. and Foekema E.M. (2014). Leaching of plastic additives to marine organisms. Environ. Pollut., 187: 49-54. doi: 10.1016/j.envpol.2013.12.013.24440692

Kosore, C.;Ojwang, L.;Maghanga, J.; Kamau, J.;Kimeli, A.;Omukoto, J.; Ngisiag'e. N.; Mwaluma J.; Ong'ada, H.; Magori, C. and Ndirui, E. (2018). Occurrence and ingestion of microplastics by zooplankton in Kenya's marine environment: first documented evidence. Afr. J. Mar. Sci., 40(3): 225-234

Kühn, S.; van Werven, B.; van Oyen, A.; Meijboom, A.A.; Bravo Rebolledo, E.L. and van Franeker, J.A. (2017). 
Kerubo J.O. et al.

The use of potassium hydroxide (KOH) solution as a suitableapproach to isolate plastics ingested by marine organisms. Mar.Pollut. Bull., 115:86-90. https://doi.org/10.1016/j.marpolbul.2 016.11 .034

Lauby-Secretan, B.; Loomis, D.; Grosse, Y.; El Ghissassi, F.; Bouvard, V.; Benbrahim-Tallaa, L. and Iarc Working Group (2013). Carcinogenicity of polychlorinated biphenyls and polybrominated biphenyls. Lancet Oncol., 14(4): 287-288.

Letourneur, Y.; Kulbicki, M. and Labrosse, P. (1998). Length-weight relationship of fishes from coral reefs and lagoons of New Caledonia: an update. Naga, the ICLARM Quarterly, 21(4): 39-46.

Leu, M.Y. and Chou, Y.H. (1996). Induced spawning and larval rearing of captive yellowfin porgy, Acanthopagrus latus (Houttuyn). Aquacult., 143(2): 155166.

Li. J.; Qu, X.; Su, L.; Zhang, W.; Yang, D.; Kolandhasamy, P.; Li, D. and Shi, H. (2016). Microplastics in mussels along the coastal waters of China. Environ. Pollut., 214:177-184. doi:10.1016/j.envpol.2016.04.012

Lieske, E. and R. Myers (1994). Collins Pocket Guide. Coral reef fishes. Indo-Pacific andCaribbean including the Red Sea. Haper Collins Publishers, $400 \mathrm{p}$.

Lithner, D.; Larsson, A. and Dave, G. (2011). Environmental and health hazard ranking and assessment of plastic polymers based on chemical composition. Sci. Total Environ., 409: 3309-3324. PMID:21663944. doi:10.1016/j.scitotenv.2011.04.038
Locham, A.G.; Kaunda-Arara, B.;Wakibia, J.G. andMuya, S. (2015). Diet and niche breadth variation in the marbled parrotfish, Leptoscarus vaigiensis, among coral reef sites in Kenya. Afr. J. Ecol., 53(4): 560-571.

Lusher, A.L.; McHugh, M. and Thompson, R.C. (2013). Occurrence of microplastics in the gastrointestinal tract of pelagic and demersal fish from the English Channel. Mar. Pollut. Bull., 67: 94-99.

Lusher, A.L. and Hollman, P.CH. and Mendoza-Hill, J.J. (2017). Microplastics in fisheries and

aquaculture: status of knowledge on their occurrence and implications for aquatic organisms and food safety. Rome: FAO Fisheries and Aquaculture Technical Paper. No.615.

Maritim, P.K.;Gachanja, A.N. andMunyao, T.M. (2016). Speciation of Trace Metals $\mathrm{Pb}, \mathrm{Zn}, \mathrm{Cu}$

and $\mathrm{Cd}$ in Superficial Sediment from Makupa Creek Mombasa Coastal Kenya. Open Access Library 3: e2679. doi.org/10.4236/oalib.1102679

Mathalon, A. and Hill, P. (2014). Microplastic fibers in the intertidal ecosystem surrounding Halifax Harbor, Nova Scotia. Mar.Pollut. Bull., 81: 69-79. PMID: 24650540. doi:10.1016/j. marpolbul.2014.02.018.

Moore, C.J. (2008). Synthetic polymers in the marine environment: a rapidly increasing long-term threat. Environ. Res., 108(2):131-139.

Nasir, N.A. (2000). The food and feeding relationships of the fish communities in the inshore waters of Khor $\mathrm{Al}$ Zubair, north-west Arabian Gulf. Cybium, 24: 89-9.

Nelms, S.E.; Galloway, T.S.; Godley, B.J.; Jarvis, D.S. and Lindeque, P.K., (2018). Investigating microplastic 
Microplastics contamination of fish from the Creeks along the Kenya coast, western Indian Ocean (WIO)

trophic transfer in marine top predators. Environ.Pollut.,238: 9991007 https://doi.org/10.1016/j.envpol .2018.02.016

Nelson, J.S. (1994). Fishes of the World. Wiley, New York, 600 pp

Neves, D.;Sobral, P.; Ferreira, J.L. and Pereira, T. (2015). Ingestion of microplastics by commercial fish off the Portuguese coast. Mar.Pollut. Bull., 101: 119-126.

Obiero, J.P. and Onyando, J.O. (2013). Climate. In Developments in Earth Surface Processes, 16: 39-50.

Okuku, E.O.; Ohowa, B.; Mwangi, S.N.; Munga, D.; Kiteresi, L.; Wanjeri, V.O.; Okumu, S. and Kilonzo, J. (2011). Sewage pollution in the coastal waters of Mombasa city, Kenya: A Norm Rather than an Exception. Environ. Res., 5(4): 865874.

Okuku, E.O.; Imbayi, K.L.; Omondi, O.G.; Wayayi, W.V.O.; Sezi, M.C.; Maureen, K.M. and Okuku, E. O., Imbayi, K. L., Omondi, O. G., Wayayi, W. V. O., Sezi, M. C., Maureen, K. M., Oduor, N. (2019). Decadal Pollution Assessment and Monitoring along the Kenya Coast. In Monitoring of Marine Pollution. IntechOpen, DOI: 10.5772/ intechopen.82606. Available from: https://www.intechopen.com/chapte $\mathrm{rs} / 66333$

Ontomwa, M. B.; Okemwa, G.M.; Kimani, E.N. and Obota, C. (2018). Seasonal variation in the length-weight relationship and condition factor of thirty fish species from the Shimoni artisanal fishery, Kenya. Western Indian Ocean J. Mar. Sci., 17(1): 103-110.

Phillips, M.B. and Bonner, T.H. (2015). Occurrence and amount of microplastic ingested by fishes in watersheds of the Gulf of Mexico. Mar.Pollut. Bull., 100 (1): 264-269.

Randall, J.E. (1986). Scaridae. In: M.M. Smith and P.C. Heemstra (eds), p. 706-714. Smiths' sea fishes. Springer-Verlag, Berlin.

Ricker, W.E. (1975). Computation and interpretation of biological statistics of fish populations. Fish. Res. Board Can. Bull., 191:1-382.

Rochman, C.M.; Hoh, E.; Kurobe, T. and Teh, S.J. (2013). Ingested plastic transferscontaminants to fish and induces hepatic stress. Nature Sci. Rep., 3: 3263.

Rochman, C.M.; Tahir, A.; Williams, S.L.; Baxa, D.V.; Lam, R.; Miller, J.T. and Teh, S.J. (2015). Anthropogenic debris in seafood: Plastic debris and fibers from textiles in fish andbivalv es sold for human consumption. Scie ntific reports, 5(1): 1-10.

Romeo, T.; Battaglia, P.; Pedà, C.; Consoli, P.; Andaloro, F. and Fossi, M. C. (2015). Firstevidence of presence of plastic debris in stomach of large pelagic fish in the Mediterranean Sea.Mar. Pollut. Bull., 95: 358-361.

Romeo, T., Peda, C., Fossi, M. C., Andaloro, F., and Battaglia, P., (2016). First record of plastic

debris in the stomach of Mediterranean lantern fishes. Acta Adriatica, 57(1):115-124.

Roux, C. (1986). Gerridae. p.325-326.In J. Daget, J.P. Gosse and D.F.E (1986).Thys van den Audenaerde (eds,) Check list of fishes of Africa (CLOFFA). ISBN, Brussels; MRAC, Tervuren; and ORSTOM, Paris.Vol.2

Rummel, C.D., (2014). Occurrence and potential effects of plastic ingestion by pelagic and demersal fish from the North Sea and Baltic Sea. 
Kerubo J.O. et al.

(Doctoral dissertation, Johannes

Gutenberg- Universität Mainz, Germany).

Saber, M.A.; Osman, H.M.; El Ganainy, A.A. and Shaaban, A. M. (2020). Improving the size-

selectivity of trammel net for Pomadasysstridens and Gerresoyena in Suez Bay, the Gulf of Suez, Red Sea. Egypt. J.Aquat. Res., 46(4), 383-388.

Sarre, G.A. and Potter, I. C. (2000). Variation in age compositions and growth rates of Acanthopagrus butcheri (Sparidae) among estuaries: some possible contributing factors. Fish. Bull., 98(4): 785-799.

Setälä, O.;Lehtiniemi, M.; Coppock, R. and Cole, M. (2018). Microplastics in marine food webs. In: Microplastic contamination in aquatic environments (pp. 339-363). Elsevier

Sheaves, M.J. (2006). Is the timing of spawning in sparid fishes a response to sea temperature regimes? Coral Reefs, 25: 655- 669. https://link. springer.com/article/10.1007/s00338 - 006-0150-5

Silva-Cavalcanti, J.S.; Silva, J.D.B.; de França, E.J.; de Araújo, M.C.B. andGusmão, F. (2017).

Microplastics ingestion by a common tropical freshwater fishing resource. Environ. Pollut., 221: 218- 226. doi:10.1016/j.envpol.2016.11.068.

Smith, J.L.B. and Smith, M.M. (1986). Family No. 183: Sparidae. In: Smith M.M. and Heemstra

P.C. ZOOTAXA (eds.), Smiths' Sea Fishes. Macmillan South Africa, Johannesburg, South Africa, pp. 580-594.
Sommer, C.; W. Schneider and J.-M. Poutiers (1996). FAO species identification field guide for fishery purposes. The living marine resources of Somalia. FAO, Rome. $376 \mathrm{p}$.

Sussarellu, R;, Suquet, M.; Thomas, Y.; Lambert, C.;Fabioux, C.;Pernet, M.E.J.; Corporeau, C., (2016). Oyster reproduction is affected by exposure to polystyrene microplastics. Proc. Natl. Acad. Sci., 113(9):2430-2435. doi.org/ 10.1073/ pnas. 1519019113 .

Thiele, C.J.; Hudson, M.D. and Russell, A.E. (2019). Evaluation of existing methods to extract microplastics from bivalve tissue: Adapted $\mathrm{KOH}$ digestion protocol improves filtration at single-digit pore size. Mar. Pollut. Bull., 142: 384-393.

Van Cauwenberghe, L.; Devriese, L.;Galgani, F.; Robbens, J. and Janssen, C.R. (2015). Microplastics in sediments: a review of techniques, occurrence and effects. Mar. Environ. Res., 111: 5-17.

Weiden, N.A.C. and Cowie, P.R. (2016). Environment and gut morphology influences microplastic retention in langoustine Nephrops norvegicus. Environ.Pollut.,214:859-856. doi.org/ 10.1016/j.envlpol.2016.03.067.

Wootton, R.J. (2012). Ecology of teleost fishes. Springer Science and Business Media. 386 pp.

Wright, S. L.; Thompson, R. C. and Galloway, T. S. (2013). The physical impacts of microplastics on marine organisms: a review. Environ. Pollut., 178: 483-492. 


$$
\text { تلوث الأسماك باللائن الدقيقة من الجداول على طول ساحل كينيا ، غرب المحيط الهندي(WIO) }
$$

\title{
Kerubo J.O. ${ }^{1^{*}}$, Muthumbi A.W.N. ${ }^{1}$, Deborah Robertson- Andersson ${ }^{2,3}$, Onyari J.M. ${ }^{4}$ and Kimani E.N. ${ }^{5}$
}

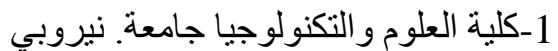

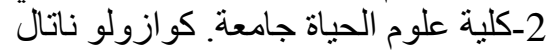

Chrysalis Nature Training, Kei mouth-3

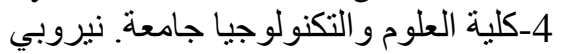

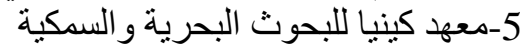

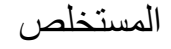

تشكل اللائن الدقيقة (MPs) تهديدًا عالميًا للحياة البحرية ، لكن المعلومات المتاحة عن مدى التلوث على على طول ساحل

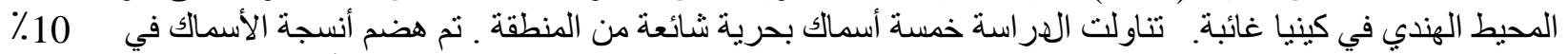

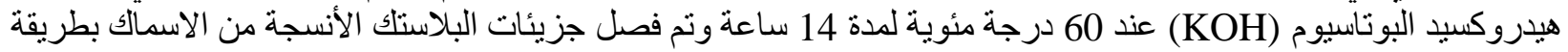

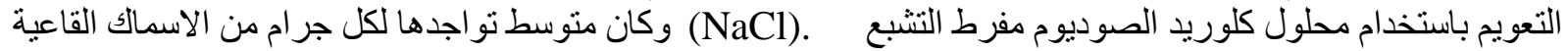

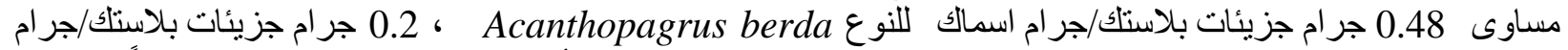

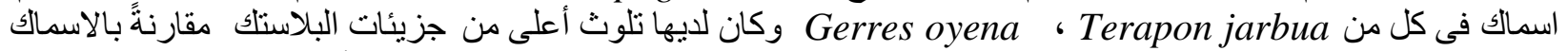
السطحية (Rastrelliger kanagurta ) (Leptoscarus vaigiensis

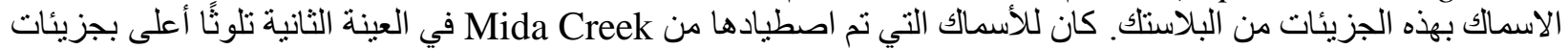

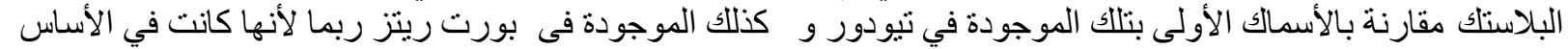

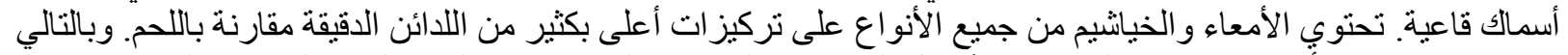

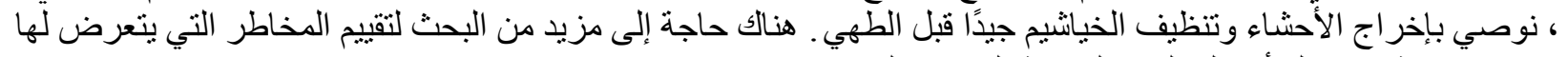
الإنسان نتيجة استهلاك أسماك المياه البحرية التي يتناولها.
\end{abstract}

